\title{
Nutritional Composition of Green Robusta Coffee (Coffea canephora) Beans under Organic and Integrated Nutrition with Varying Shade and Irrigation Management Practices in Western Ghats of India
}

\author{
S.B. Hareesh, Jayarama
}

10.18805/ajdfr.DR-1679

\begin{abstract}
Background: Cultural practices and environment may affect the physical, chemical, microbiological and nutritional qualities of the raw beans. With the advent of nutritional labelling regulations (FDA, 1973), many coffee bean processors have incorporated nutrition information on their products for label declaration. The current field experiment aimed to study to know the influence of nutrient management practices, irrigation and shade pattern on nutrient status of green coffee beans and yield of robusta coffee.

Methods: This field-laboratory experiment was carried out at nine selected robusta coffee estates located at Western Ghats of India, i.e., Koppa region of Chikkamagaluru District, situated in the south western part of Karnataka State. The experiment was laid out in randomized block design (RBD) with 25 plants per treatment (plot size- $112 \mathrm{~m}^{2}$ ) with four replications. Representative coffee fruits from the experimental blocks were collected during harvesting period (February-March). After harvesting of the fruits they were wet processed to remove pulp and mucilage from the fruits. Further, they were sun dried up to 10 percent moisture level and stored using standard methods.

Result: The green coffee bean $\mathrm{N}$ and $\mathrm{P}$ concentration remained higher ( 3.1 and $0.37 \%$ ) in INM mode of nutrition compared to that of exclusive organics (3.0 and $0.36 \%$ ). Within organic mode of nutrition, the shade pattern and irrigation schedule imparted difference in $\mathrm{N}$ assimilation. The bean $\mathrm{K}$ content did not vary between the INM and organic nutrition modes as depicted by similar (1.8\%) values. However, within organic mode of nutrition, the shade pattern and irrigation schedule imparted difference in $\mathrm{K}$ assimilation. The average bean yield remained higher $\left(1230 \mathrm{~kg} \mathrm{ha}^{-1}\right)$ in INM mode of nutrition compared to that of exclusive organics (1101 $\left.\mathrm{kg} \mathrm{ha}^{-1}\right)$.
\end{abstract}

Key words: Nutritional composition, Organic and integrated nutrition, Robusta coffee (Coffea canephora) beans.

\section{INTRODUCTION}

Since the origin of humanity, plant foods have been used to promote health and preclude disease. A successful cropping system depends upon the appropriate management of resources along with the balanced use of manures and fertilizers (Sodavadiya et al., 2021). Coffee has been dignified by people of diverse countries and eras because of its stimulating and health-promoting effects along with its distinctive aroma and taste (Bizzo et al., 2015). Around the world, Arabica coffee (Coffea arabica) and Robusta coffee (Coffea canephora) are the most popular species found and consumed beverages. In terms of chemical composition, coffee brew exhibits very high variability due to many possible variations in raw material production, processing and brewing, which lead to the final product (Adriana Farah, 2018). In the prevailing agricultural production scenario, the use and recycling of organic matter are becoming inevitable particularly for the export-oriented commodities such as coffee, due to cumulative demands of the sustainably produced agricultural crop for environmental, social and food safety reasons. Sustainable production is becoming an essential component for the coffee sector to endure the competition in the global trade against oversupply and price fluctuations that result in a crisis in coffee price. Long-term
Division of Agricultural Chemistry, Central Coffee Research Institute, Coffee Research Station, Chikkamagaluru-577 117, Karnataka, India.

Corresponding Author: S.B. Hareesh, Division of Agricultural Chemistry, Central Coffee Research Institute, Coffee Research Station, Chikkamagaluru-577 117, Karnataka, India.

Email: hareeshsb@gmail.com

How to cite this article: Hareesh, S.B., Jayarama (2021). Nutritional Composition of Green Robusta Coffee (Coffea canephora) Beans under Organic and Integrated Nutrition with Varying Shade and Irrigation Management Practices in Western Ghats of India. Asian Journal of Dairy and Food Research. DOI: $10.18805 /$ ajdfr.DR-1679.

Submitted: 09-04-2021 Accepted: 04-10-2021 Online: 03-11-2021

reliance on inorganic fertilizers may not be sustainable in the enduring, due to consistent usage of inorganic fertilizers soils become acidic, may decline microbial population, unstable soil aggregates leading to erosion, general degradation and ultimately decline in crop productivity (Nyalemegbe et al., 2009).

The use of organic manures is the oldest and extensively practiced resources of nutrient replenishment in India. Organic manures have a significant role to play in nutrient 
Nutritional Composition of Green Robusta Coffee (Coffea canephora) Beans under Organic and Integrated Nutrition....

supply besides improving soil physicochemical properties and soil health. Similarly, soil organic matter plays an important role in moisture retention and consequently the utilization of organic manures is considered as a climate change adaptation strategy. Soil moisture is important in the decomposition of organic matter and contributing nutrients from both organic manures and inorganic fertilizers available to the plant (El-Kader et al., 2010). The supplementary and complimentary use of organic manure moreover improves the efficiency of mineral fertilizers used. Though, generally lower plant performance was observed in the case of exclusive organics compared to conventional systems, due to the slow release of nutrients by organic manures in comparison with mineral fertilizers. Conversely, a number of studies have shown that organic manures are very important for maintaining soil organic matter and supplying nutrients to the coffee systems, but may not be enough for balanced plant nutrient flows and for achieving profitable yield levels (Stockdale et al., 2002). Since, the maximum $\mathrm{N}$ available from common organic manures is $<10 \%, \mathrm{P}<2 \%$ and $\mathrm{K}<10 \%$ of dry matter compared with high nutrient outflows of up to $105 \mathrm{~kg} \mathrm{ha}^{-1}$ of $\mathrm{N}, 13 \mathrm{~kg} \mathrm{ha}^{-1}$ of $\mathrm{P}$ and $107 \mathrm{~kg} \mathrm{ha}^{-1}$ of $\mathrm{K}$ to achieve yield levels of $1 \mathrm{t} \mathrm{ha}^{-1}$ per year resulting in serious negative nutrient balances (Van der Vossen, 2005). The negative nutrient balance resulted from the exclusive use of organic manures is apparent in cropping coffee plants. At this juncture, integrated nutrient management (INM) is able to provide a positive nutrient balance for sustainable coffee production. It is evident that $120: 90: 120 \mathrm{~kg}$ of $\mathrm{N}: \mathrm{P}_{2} \mathrm{O}_{5}: \mathrm{K}_{2} \mathrm{O}$ to produce $1 \mathrm{MT}$ clean coffee beside sustenance does 20:20:20 kg of $\mathrm{N}$ : $\mathrm{P}_{2} \mathrm{O}_{5}: \mathrm{K}_{2} \mathrm{O}$. Further, the increased sustenance dose of 30:30:30 kg NPK is recommended for yields exceeding $1 \mathrm{MT}$. The fertilizer use efficiency at the rate of 40,10 and 50 percent for $\mathrm{N}, \mathrm{P}$ and $\mathrm{K}$, respectively expected in the coffee-growing soils form the basis for the above recommendation (Jayarama, 2001). Intensive production of Robusta coffee uptakes substantial amounts of nutrients from the soil to develop good quality green coffee beans associated with pulp and parchment. It has been estimated that the major nutrients removed in one ton of coffee green beans may be 33-63 kg N, 2-11 kg $\mathrm{P}_{2} \mathrm{O}_{5}$ and 47-67 $\mathrm{kg} \mathrm{K} \mathrm{K}_{2} \mathrm{O}$ depending on soil type and fertilizer application (Anonymous, 2014). Therefore, a sustainable coffee production system must replace nutrient losses in addition to those removed with the crop (Tiemann et al., 2018). Sustainable production is becoming inevitability for coffee sectors to stay competitive in the global trade against oversupply and price fluctuations that in some years result in coffee price crisis (Abel Chemura, 2014).

Worldwide, coffee is predominantly cultivated as a rainfed crop. In India, coffee usually encounters 90-120 days of dry spells in a year. Under such conditions, growth and productivity could be boosted substantially by irrigation and this is very important in the case of Robusta coffee. Coffee, which is an evergreen plant, requires maintenance of soil moisture during dry months. The drought period usually consists of four months from December onwards. The long drought period is the most limiting factor for coffee production even in well-managed estates. Rainfall pattern decides the crop production at field conditions, if blossom rains are delayed beyond April then the production of coffee would be hampered. In coffee, irrigation is mainly used as insurance against the failure of adequate blossom and backing showers and for overcoming long droughts. Timely irrigation is progressively becoming imperative for coffee production to mitigate climate change such as unreliable rainfalls and frequent droughts that affect the growth, yield and quality of coffee (Worku and Astatkie, 2010). This is despite the fact that soil water is important for keeping plant nutrients in solution, maintaining soil microorganisms and for root and shoot development and functioning, all of which have an impact on production levels and quality (Stockdale et al., 2002). Irrigation water management is a very critical component in the coffee production system. Excessive irrigation is expensive and moisture stress consequences in dieback, wilting, opportunistic disease and pest attacks, resulting in reduced production in both cases. Further, moisture stress can also result in floral abortion during interim estate conditions and ultimately results in reduced coffee production. The interaction between nutrient sources, shade and timely irrigation is therefore very imperative for sustainable coffee production, principally in the prevailing situation of reducing production costs and acclimating to climate change for the coffee industry.

All the merits of shading in coffee plantations have been discussed by many authors showed that shade conditions in coffee plantations, although not required, are highly profitable for organic farming (Inge de Groot, 2001). Coffee, like many other tropical tree crops, has a high potential for environment-friendly agricultural production especially when grown in a kind of agroforestry system (Smith, 2000). Shade thus under South Indian conditions acts as-a buffer and most beneficial against vagaries of climate and their adverse effect (Krishnamurthy Rao and Ramaiah, 1993). In the coffee agroforestry systems, shade trees contribute to the formation of litter which, after decomposition, can influence nutrient levels in soil (Campanha et al., 2004). Coffee requires much higher levels of nutrient inputs and crop management to achieve environmental sustainability than generally assumed by the proponents of organic agriculture (Van Elzakker, 2001). The nutrient cycling processes in organically and conventionally managed soils are similar, organic matter is very important in maintaining soil quality, but additional inputs of inorganic fertilizers remain necessary for balanced plant nutrient flows and adequate yield levels (Van Der Vossen, 2005). In coffee plants, nitrogen (N), phosphorous $(\mathrm{P})$ and potassium $(\mathrm{K})$ are considered as the major nutrients and have one or more essential roles in the development of beans. Nitrogen is important for protein synthesis, hence the quality of the beans. Phosphorus helps in fruit set, while potassium is necessary for berry development and ripening. Higher potassium content is reported to lower the quality of beans. Sulfur is an important constituent of some essential amino acids (cysteine, cystine 
and methionine); its deficiency lowers protein quality. The high $\mathrm{Ca}$ and low $\mathrm{Fe}$ of beans influence a reduction in the acidity and body of the beverage, $\mathrm{Mg}$ deficiency may also affect the beverage quality (Amorim, 1970). High calcium content may also lead to iron deficiency. Iron deficient trees are reported to produce 'Amber beans' which give a bitter flavor to the liquor. Hence, balanced nutrition will protect the intrinsic bean quality (Nataraj et al., 1998). It is well known that the application of fertilizers in crop production will affect the composition of plant material (Nagy and Wardowski, 1988 and Linder, 1991). The utilization of integrated fertility management can be the most attractive opportunity, given that it reduces both costs of inorganic fertilizers and also on quantities of composts required for efficient coffee growth (Abel Chemura, 2014). Similarly, Tesfaye Bayu (2020) concluded that; INM improves yield and yield components for different crops, important to mitigate climate change in conjunction with sustainable agricultural production. Since information on organic and integrated nutrition on nutrient status of Robusta coffee beans is meager; therefore the present study is conducted for the first time to ascertain the impact of organic and integrated nutrient management practices, shade and irrigation levels on the nutrient status of green coffee (SI.274) beans.

\section{MATERIALS AND METHODS}

\section{Study location}

This field experiment was carried out at 9 selected Robusta coffee estates located at Western Ghats of India, i.e., Koppa region of Chikkamagaluru District, which is situated in the Southwestern part of Karnataka State, between $12^{\circ} 54^{\prime}$ and $13^{\circ} 53^{\prime}$ north latitude and between $75^{\circ} 04^{\prime}$ and $76^{\circ} 21^{\prime}$ east longitudes. 2,509 $\mathrm{m}$ above sea level, with an average mean annual rainfall of $2908 \mathrm{~mm}$. The tropical climate prevails in the study location, the relative humidity ranges from 27 to $80 \%$ and the average wind speed ranges from between 4 to $7 \mathrm{~km} / \mathrm{hr}$. The climate in the study location is having three distinct seasons; 1) Summer season - March to early June, 2) Monsoon season - early June to September, however very little rainfall occurs during October to November due to impact North East Monsoon, 3) Winter season begins in mid-November and ends in the middle of February. Among the selected 9 coffee estates, four estates practice organic mode of nutrition, while four estates follow integrated nutrition management (INM) practice and one estate where no nutrition management was practiced (absolute control). Varying shade patterns (open and thick) and irrigation (blossom, backing and winter) are the differentiation factors in the selected estate's practiced exclusive organic cultivation and integrated nutrient management. The experiment was laid out in randomized block design (RBD) with 25 plants per treatment (plot size- $112 \mathrm{~m}^{2}$ ) with 4 replications. The selected estates under organic cultivation were practiced organic farming for the preceding four years. The other cultural practices were carried out as per the standard package of practices (Anonymous, 2003). The treatment details are as follows.

T1- Control.

T2- Organic nutrition ${ }^{*}$, thick shade (TS - 50 to 60\% canopy) + Irrigation - I (winter).

T3- Organic nutrition ${ }^{\star}$, thick shade (TS - 50 to 60\% canopy) + Irrigation -II (Blossom and Backing).

T4- Organic nutrition ${ }^{\star}$, optimum shade (OS - 25 to 30\% canopy) + Irrigation - II (Blossom and Backing).

T5- Organic nutrition ${ }^{\star}$, optimum shade (OS - 25 to 30\% canopy) + Irrigation - I (winter).

T6- INM ${ }^{\#}$, thick shade (TS - 50 to $60 \%$ canopy) + Irrigation - I (winter)

T7- INM", thick shade (TS - 50 to $60 \%$ canopy) + Irrigation (Blossom and Backing) - II.

T8- INM", optimum shade (OS - 25 to $30 \%$ canopy) + Irrigation - II (Blossom and Backing).

T9- INM", optimum shade (OS - 25 to $30 \%$ canopy) + Irrigation - I (winter).

*Organic nutrition - 100\% organics [Farm Yard Manure and Compost -2.5 tones ha-1 ${ }^{-1}$ Rock phosphate 0.2 tones ha-1].

\#Integrated nutrition - [50\% recommended dose of fertilizer (Anonymous, 2003) $+50 \%$ organic manures].

Winter-irrigation (I): At least four irrigations at winter, blossoming, backing and summer (interval of twenty days), extended if dry spell continuous.

Blossom backing irrigation (II): Irrigations at blossoming and backing.

\section{Experimental design and sample collection}

The experiment was laid out in randomized block design (RBD) with twenty five plants per treatment (plot size- 112 $\mathrm{m}^{2}$ ) with four replications. The organics estates were selected where organic farming practices were practiced in the preceding four years. The experiment was conducted for three years and representative coffee fruits from all nine Robusta growing coffee estates were collected during the harvesting period (February-March). After harvesting the fruits, they were wet-processed to remove pulp and mucilage from the fruits. Further, they were sun-dried up to 10 percent moisture level and stored using standard methods followed in parchment coffee (Anonymous, 2003). The nutrient analysis of coffee beans was carried out at Central Coffee Research Institute, Coffee Research Station, Chikkamagaluru - District, Karnataka. The bean fractions were subjected to Di-acid digestion (Hydrochloric acid + Perchloric Acid - 9:4) except nitrogen. For nitrogen analysis, sulphuric acid digestion followed by the Kjeldahl procedure was employed. The data were subjected to appropriate statistical analysis as suggested by Gomez and Gomez (1984) to draw valid inferences. The coffee yield was evaluated by harvesting the entire selected plants (10 plants per treatment per replication). The berries were dried until a constant weight was reached. The yield was calculated as per hectare base. The spacing between plants and between rows was the same for treatments. 


\section{Analysis of chemical composition of bean}

Nitrogen $(\mathrm{N})$ content in the green beans was determined by Micro-Kjeldahl's Method as described by Dhyan Singh et al., (1999) using Automatic Nitrogen Analyzer (Vapodest - 30), phosphorous content was analyzed using Vanadomolybdo phosphoric yellow color method, the method (Dhyan Singh et al., (1999) and potassium content by flame photometer method (Jackson, 1973). The sulfur analysis by Turbidometric method, calcium and magnesium content was analyzed by using Atomic Absorption Spectrophotometer (GBC-932AA) as described by Jackson (1973). The microelements $\mathrm{Cu}$, $\mathrm{Zn}, \mathrm{Fe}$ and $\mathrm{Mn}$ are analyzed by using Atomic Absorption Spectrophotometer (GBC-932AA) as described by Jackson (1973).

\section{RESULTS AND DISCUSSION \\ Green coffee beans chemical composition}

By using analytical data comparisons are made between organic and integrated nutrient management against the backdrop of standard control. Bean nitrogen $(\mathrm{N})$ content is of paramount importance as it is the vital constituent for proteins and amino acids involved in the formation of the final product. In general, average the bean $\mathrm{N}$ concentration remained higher $(3.1 \%)$ in the INM mode of nutrition compared to that of exclusive organics (3.0\%). Within the organic mode of nutrition, the shade pattern and irrigation schedule imparted a difference in $\mathrm{N}$ assimilation. The open shade resulted in slightly elevated $(3.1 \%)$ bean $\mathrm{N}$ compared to thick shade $(2.8 \%)$. Similarly, winter irrigation revealed higher $(3.1 \%) \mathrm{N}$ assimilation compared to the beans under blossom and backing irrigation (2.95\%). Studies on irrigation levels and $\mathrm{N}$ rates on coffee showed that the high rates of $\mathrm{N}$ are effective when there is minimum water depletion (Ibrahim and El-Samad, 2009 and Kutywayo et al. 2010). The same pattern of differences was evident in INM mode where open shade resulted in slightly elevated $(3.1 \%)$ bean $\mathrm{N}$ compared to thick shade $(3.0 \%)$ and winter irrigation revealed higher (3.2\%) N assimilation compared to the leaves under blossom and backing irrigation (2.9\%). Overall, $\mathrm{N}$ assimilation in the bean was favoured by INM mode of nutrition, besides additive effects seen under open shade and winter irrigation. The majority of the studies indicate that the higher the amount of nitrogen available to the crops, the higher its uptake and as a consequence the higher the nitrogen and nitrate contents of the crop. Fruit tissue $\mathrm{N}$ levels were statistically higher in the INM system compared to the organic system. Augmented N status in fruit trees is known to increase fruit size, but along with lower $\mathrm{Ca}$ and $\mathrm{P}$ concentrations, delays color development and reduce fruit firmness (DeEll and Prange, 1993; Stiles, 1994). Further in Brazil, nitrogenous manuring was found to increase $\mathrm{N}$ content in the bean and a negative but significant correlation was found at a $1 \%$ level between $\mathrm{N}$ content in bean and beverage quality (Amorim, 1970).

In general, the bean phosphorus concentration remained higher $(0.37 \%)$ in the INM mode of nutrition compared to that of exclusive organics $(0.36 \%)$. Within the organic mode of nutrition, the shade pattern and irrigation schedule imparted difference in $\mathrm{P}$ assimilation. The open shade, as well as winter, irrigated treatments resulted in slightly elevated $(0.38 \%)$ bean $\mathrm{P}$, compared to thick shade and limited irrigation during blossom and backing treatments $(0.35 \%)$. The same pattern of differences was evident in INM mode where open shade, as well as winter, irrigated treatments resulted in slightly elevated $(0.38 \%)$ bean $P$, compared to thick shade and limited irrigation during blossom and backing treatments $(0.36 \%)$. Overall, $\mathrm{P}$ accumulation in the bean was favored by INM mode of nutrition, besides additive effects seen under open shade and winter irrigation. Increased P supply from the INM mode increases the total $P$ concentration in the vegetative and reproductive parts, thus improve crop quality. Higher $P$ accumulation in beans improves other value-determining substances, such as essential amino acids in the grains and carbohydrates (sugar and starch) and vitamins (FAO, 2006).

The bean $\mathrm{K}$ content did not vary between the INM and organic nutrition modes as depicted by similar (1.8\%) values. However, within the organic mode of nutrition, the shade pattern and irrigation schedule imparted differences in $\mathrm{K}$ assimilation. On average, the open shade resulted in slightly elevated $(1.8 \%)$ bean $\mathrm{K}$ compared to thick shade $(1.65 \%)$. Similarly, winter irrigation revealed higher $(1.8 \%) \mathrm{K}$ assimilation compared to the beans under blossom and backing irrigation (1.75\%). The same pattern of differences was evident in INM mode where the open shade, as well as winter, irrigated treatments resulted in slightly elevated (1.85\%) bean $\mathrm{K}$, compared to thick shade and limited irrigation during blossom and backing treatments (1.75\%). Potassium accumulation in the bean was favored by the INM mode of nutrition, besides additive effects seen under open shade and winter irrigation. Among plant nutrients, $\mathrm{K}$ content is very closely associated with crop quality. It is required for superior growth in addition to excellent crop quality. By greatly affecting enzyme activity and through osmotic regulation, $\mathrm{K}$ affects the entire metabolism of the coffee plant, especially photosynthesis and carbohydrate production. The ash content of green coffee is about 4 per cent (dry matter basis) of which 40 percent is potassium (Raghavan and Ramalakshmi, 1998). Higher K accumulation in the bean was ensured in the INM nutrition mode. The Effect of organic and INM under differential shade patterns and irrigation schedules on and bean nutritional status are made available in Table. 1 and nutrient assimilation is presented in the Fig 3.

Sulphur (S) concentration in beans was improved in the INM nutrition mode compared to exclusive organics. In general, the bean S concentration remained higher $(0.17 \%)$ in the INM mode of nutrition compared to that of exclusive organics $(0.12 \%)$. Within the organic mode of nutrition, the shade pattern and irrigation schedule imparted a difference in $\mathrm{S}$ assimilation. The open shade resulted in slightly elevated $(0.14 \%)$ bean S compared to thick shade $(0.11 \%)$. Similarly, winter irrigation revealed higher $(0.13 \%)$ 
Nutritional Composition of Green Robusta Coffee (Coffea canephora) Beans under Organic and Integrated Nutrition....

$\mathrm{S}$ assimilation compared to the beans under blossom and backing irrigation $(0.12 \%)$. The same pattern of differences was evident in INM mode where open shade resulted in slightly elevated $(0.22 \%)$ bean $\mathrm{S}$ compared to thick shade $(0.12 \%)$ and winter irrigation revealed higher $(0.19 \%) \mathrm{S}$ assimilation compared to the leaves under blossom and backing irrigation $(0.15 \%)$. Sulphur assimilation in the bean was favoured by the INM mode of nutrition, besides additive effects seen under open shade and winter irrigation. Sulphur is an important constituent of some essential amino acids; its deficiency lowers protein quality. The analytical results are depicted in Fig 1.

Several researchers (Mahajan et al., 2008; Gafar et al., 2012) have demonstrated the beneficial effect of integrated nutrient management in mitigating the deficiency of several macro-and micro-nutrients. Similarly, in the present investigation, Calcium (Ca) concentration in beans was improved in the INM nutrition mode compared to exclusive organics. In general, the bean $\mathrm{Ca}$ concentration remained higher $(0.09 \%)$ in the INM mode of nutrition compared to that of exclusive organics $(0.08 \%)$. Within the organic mode of nutrition, the shade pattern and irrigation schedule imparted a difference in $\mathrm{Ca}$ assimilation. The open shade resulted in slightly elevated $(0.09 \%)$ bean $\mathrm{Ca}$ compared to thick shade $(0.07 \%)$. Similarly, winter irrigation revealed higher $(0.09 \%)$ Ca assimilation compared to the beans under blossom and backing irrigation $(0.08 \%)$. The same pattern of differences was evident in INM mode where the open shade, as well as winter irrigated treatments resulted in slightly elevated $(0.1 \%)$ bean, Ca compared to thick shade and limited irrigation during blossom and backing treatments $(0.08 \%)$. The high $\mathrm{Ca}$ of beans under INM, influence a reduction in the acidity and improves the body of the beverage (Amorim, 1970). The magnesium content in the bean did not vary amongst the modes of nutrition, shade pattern and irrigation schedule. The Magnesium (Mg) content remained higher than $\mathrm{Ca}$ and $\mathrm{Mg}$ deficiency may also affect the beverage quality (Amorim, 1970). Similarly, adequate accumulation of all the micronutrients was ensured in all the treatments irrespective of nutrition mode, shade pattern and irrigation schedule. The analytical data is presented in Fig 2.

\section{The coffee yield}

The average bean yield over two years under differential shade pattern and irrigation schedule with organics and INM are made available in Table 2. In general, the average bean yield remained higher $\left(1230 \mathrm{~kg} \mathrm{ha}^{-1}\right)$ in the INM mode of nutrition compared to that of exclusive organics (1101 kg ha-1). For coffee plants, the optimum supply of soil nutrients from organic and inorganic fertilization leads to giving good yields

Table 1: Effect of organic and integrated nutrition on nutrient composition of green coffee beans.

\begin{tabular}{lcccccccccc}
\hline Treatments & $\mathrm{N}(\%)$ & $\mathrm{P}(\%)$ & $\mathrm{K}(\%)$ & $\mathrm{S}(\%)$ & $\mathrm{Ca}(\%)$ & $\mathrm{Mg}(\%)$ & $\mathrm{Cu}(\mathrm{ppm})$ & $\mathrm{Zn}(\mathrm{ppm})$ & $\mathrm{Fe}(\mathrm{ppm})$ & $\mathrm{Mn}(\mathrm{ppm})$ \\
\hline T 1 & 2.5 & 0.33 & 1.5 & 0.1 & 0.05 & 0.15 & 13.7 & 5.1 & 89 & 9.5 \\
T 2 & 3.0 & 0.36 & 1.8 & 0.12 & 0.08 & 0.17 & 21.1 & 6.1 & 108 & 10.8 \\
T 3 & 2.9 & 0.34 & 1.7 & 0.1 & 0.07 & 0.16 & 22.6 & 7.5 & 129 & 12.1 \\
T 4 & 3.0 & 0.36 & 1.8 & 0.13 & 0.08 & 0.17 & 26.4 & 8.6 & 139 & 14.6 \\
T 5 & 3.2 & 0.39 & 1.8 & 0.14 & 0.10 & 0.17 & 23.9 & 7.3 & 121 & 12.2 \\
T 6 & 3.1 & 0.37 & 1.8 & 0.12 & 0.09 & 0.17 & 22.5 & 6.1 & 107 & 11.9 \\
T 7 & 2.9 & 0.35 & 1.7 & 0.11 & 0.07 & 0.14 & 23.7 & 8.1 & 134 & 12.3 \\
T 8 & 2.9 & 0.37 & 1.8 & 0.18 & 0.08 & 0.17 & 26.7 & 9.6 & 141 & 13.8 \\
T 9 & 3.3 & 0.39 & 1.9 & 0.25 & 0.11 & 0.18 & 24.1 & 8.2 & 117 & 12.3 \\
Sem \pm & 0.28 & 0.04 & 0.13 & 0.03 & 0.03 & 0.02 & 0.64 & 0.24 & 2.1 & 0.5 \\
CD at 5\% & 0.57 & NS & 0.27 & 0.06 & NS & NS & 1.32 & 0.49 & 4.3 & 1.0 \\
\hline
\end{tabular}

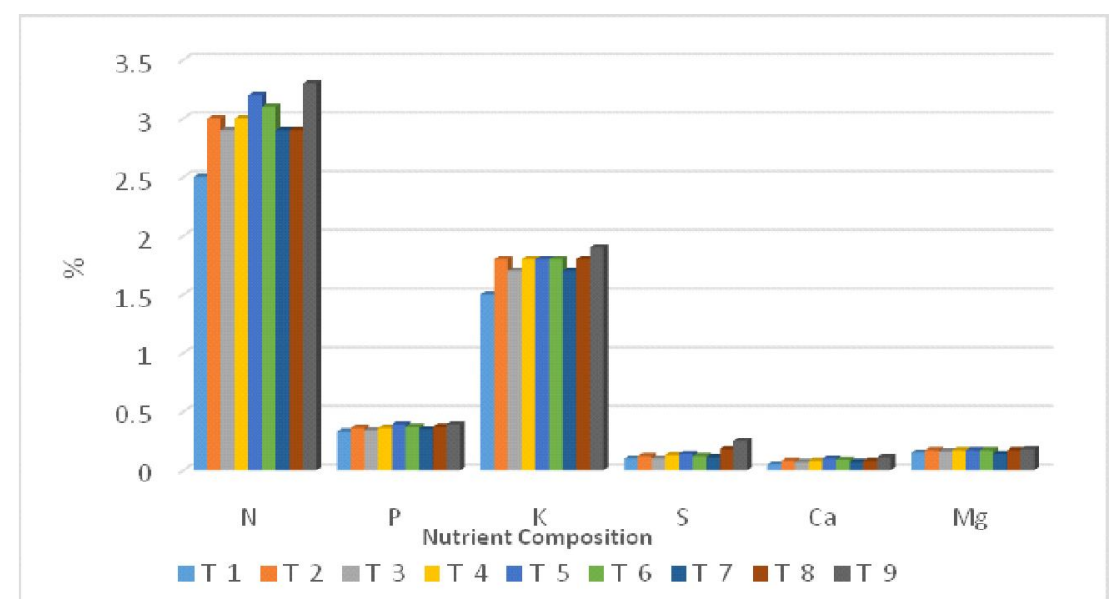

Fig 1: Effect of organic and INM on major and secondary nutrient composition of green coffee beans. 
(Yitagesu and Shimels (2020). Similar results were also concluded in many other crops viz., cluster bean (Cyamopsis tetragonoloba) by Baljinder Singh and Rakesh Kumar (2016), in French bean (Phaseolus vulgaris L.) by (2017), in Malt Barley (Hordeum distichon L.) by Randhawa et al., (2020), in chickpea by Sodavadiya et al., (2021); in Sesame (Sesamum indicum L.) by Sangma et al., (2021); where crop

Table 2: Yield (cc kg/ha) of Robusta coffee influenced by organic and integrated nutrition with varying shade and irrigation management practices.

\begin{tabular}{lccc}
\hline Treatments & First yr. & Second yr. & Mean \\
\hline T1 & 340 & 310 & 325 \\
T2 & 1225 & 1075 & 1150 \\
T3 & 625 & 500 & 562.5 \\
T4 & 950 & 850 & 900 \\
T5 & 1800 & 1780 & 1790 \\
T6 & 1456 & 1400 & 1428 \\
T7 & 692 & 652 & 672 \\
T8 & 990 & 900 & 945 \\
T9 & 1895 & 1855 & 1875 \\
F' test & & & $*$ \\
Sem \pm & & & 40.87 \\
CD at 5\% & & & 86.24 \\
\hline
\end{tabular}

* Mean of 2 years data - clean coffee $\mathrm{kg} / \mathrm{ha}$. yields significantly increased by combine application of chemical fertilizers and organic manures (INM). Within the organic mode of nutrition, the shade pattern and irrigation schedule imparted a difference in yield realization. Since, generally, shade trees have a pivotal role in creating ambient micro-climate for coffee plantations in particular and for the integral ecological system of the coffee tracts (Alemu, 2015). The open shade resulted in a slightly higher $\left(1345 \mathrm{~kg} \mathrm{ha}^{-1}\right)$ yield compared to thick shade (856 kg ha-1). Similarly, winter irrigation revealed a higher (1470 kg ha-1) yield compared to the beans under blossom and backing irrigation $(731 \mathrm{~kg}$ $\left.\mathrm{ha}^{-1}\right)$. The same pattern of differences was evident in INM mode where open shade resulted in slightly higher (1410 $\left.\mathrm{kg} \mathrm{ha}^{-1}\right)$ yield compared to thick shade $\left(1050 \mathrm{~kg} \mathrm{ha}^{-1}\right)$ and winter irrigation revealed higher (1652 $\mathrm{kg} \mathrm{ha}^{-1}$ ) yield compared to the leaves under blossom and backing irrigation $\left(809 \mathrm{~kg} \mathrm{ha}^{-1}\right)$. The highest (1875 kg ha ${ }^{-1}$ ) yield was observed in the treatment with INM nutrition mode under open shade and winter irrigation followed by T5 $\left(1790 \mathrm{~kg} \mathrm{ha}^{-1}\right)$ where all the things remained constant except a shift in the nutrition pattern from INM to exclusive organics. Similar observations were also observed in summer green gram by Tyagi et al., (2014), where increased availability of nutrients owing to the use of INM resulted in greater translocation of photosynthates from the source to sink site that resulted in higher yield.

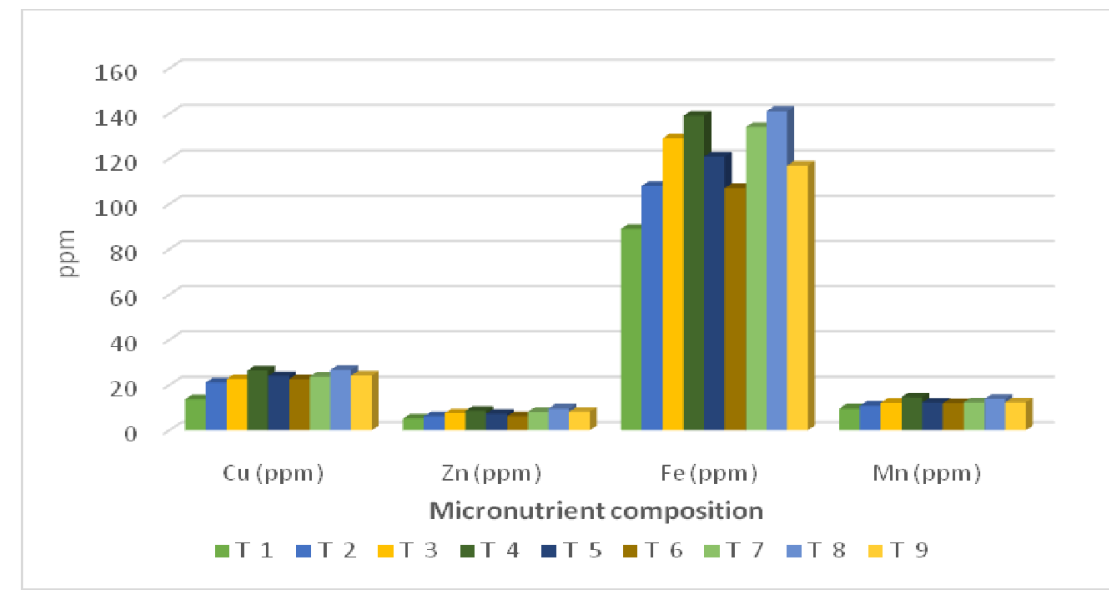

Fig 2: Effect of organic and INM on micronutrient composition of green coffee beans.

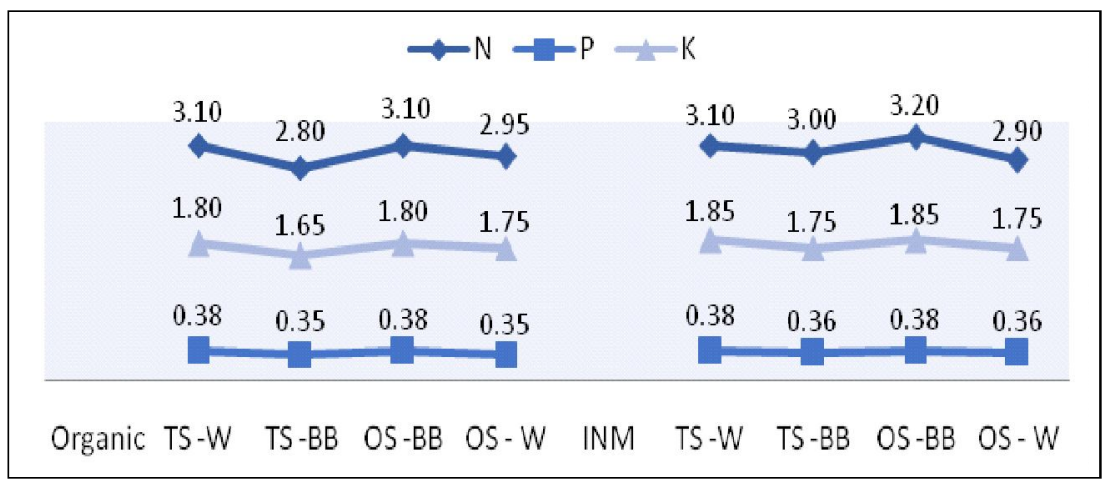

Fig 3: Effect of organic and INM on nutrient assimilation in green coffee beans. 
The hierarchy of yield attributes was nutrition mode (INM better than organics), followed by irrigation schedule (winter irrigation better than blossom and backing irrigation) and shade pattern (open shade better than thick shade). The surest way to maintain soil fertility and increase yields is by a combination of organic and inorganic manuring. A favourable soil structure, on the other hand, is maintained by mulching or shading. By the skilful combination of these measures, the yields increase appreciably (Kesavamurthy, 1971). Correct fertilization can have a positive impact on the quality of coffee. Mineral, protein, vitamin, acidity colour and flavour components of coffee may be improved if judicious fertilization is undertaken which also correct the previously existing inadequate level of nutrient availability (Jayarama, 2001). In most long-term experiments, combined use of mineral fertilizers and farmyard manure has usually produced the highest crop yields (Wang et al., 2002). From an agronomic point of view, there is also considerable ground for criticism on the principles of organic farming when applied to coffee (Vander Vossen, 2004). One of the benefits of organic farming is that it may reduce costs, although yields tend to decrease (Kotchi, 1990). To sustain economically viable yield levels (1-tonne green coffee/ha/year) large additional amounts of composted organic matter will have to supplement from external sources to meet nutrient requirements (especially $\mathrm{N}$ and $\mathrm{K}$ ). Most smallholders will be unable to acquire such quantities and have to face declining yields (Vossen, 2004). In coffee, smallholder farms with no access to external inputs produce annually often less than $300 \mathrm{~kg}$ of green coffee beans per ha, while intensively managed plantations of robusta coffee at conventional spacing may yield annually up to 3.5 tonnes per ha averaged over several years (Söndahl et al., 2004).

\section{CONCLUSION}

The bean nutrient and biochemical status indicated that the INM mode was superior over exclusive organics in maintaining higher nutrient concentration. The most congenial conditions created with respect to nutrient availability and ideal soil reaction coupled with accelerated nutrient assimilation and efficient conversion into photosynthates in the INM mode of nutrition facilitated higher nutrient accumulation in the bean compared to exclusive organics treatments. Further, the open shade was found to be superior compared to that thick shade in nutrient assimilation as well as the synthesis of photosynthates. Similarly, the winter irrigation (irrigation at specified intervals throughout the dry spell) was found to be better than the limited irrigations during blossom and backing for assimilation of nutrients and effective transformation into photosynthates. To conclude, the combination of INM nutrition mode under the open shade with winter irrigation was found to be appropriate in realizing higher yields with desired bean nutrient composition. Therefore, by considering all the above outcomes integrated nutrition practice (INM) is recommended for sustainable eco-friendly coffee production in the Western Ghats of India.

\section{REFERENCES}

Abel Chemura. (2014). The growth response of coffee (Coffea arabica L.) plants to organic manure, inorganic fertilizers and integrated soil fertility management under different irrigation water supply levels. International Journal of Recycling of Organic Waste in Agriculture. 3: 59(1-9).

Adriana Farah. (2018). Nutritional and Health Effects of Coffee. Edited by Dr Philippe Lashermes. Achieving Sustainable Cultivation of Coffee. Burleigh Dodds Series in Agricultural Science, Cambridge, UK. Pp. 1-31.

Alemu, M.M. (2015). Effect of tree shade on coffee crop production. Journal of Sustainable Development. 8(9): 66-70.

Amorium, H.V. de. (1970). Nutritional status of the coffee plant and bevenge quality. Indian Coffee. 84: 331-335.

Anonymous. (2003). Coffee Guide, Published by Coffee Board, India.

Anonymous. (2014). Coffee Guide; Central Coffee Research Institute, Coffee Research Station: Chikmagalur District, Karnataka, India.

Baljinder Singh and Rakesh Kumar. (2016). Effect of integrated nutrient management on growth, yield and nutrient uptake of clusterbean (Cyamopsis tetragonoloba) under irrigated conditions. Agric. Sci. Digest. 36(1): 35-39.

Bizzo, M.L.G., Farah, A., Kemp, J.A. and Scancetti, L.B. (2015). Highlight in the History of Coffee Science Related to Health. In: Coffee in Health and Disease Prevention. [Preedy, V. (Ed.)]. Elsevier, London, UK, pp.11-18.

Campanha, M.M., Santos, R.H.S., Freitas, G.B.d., Martinez, H.E.P., Garcia, S.L.R. and Finger, F.L. (2004). Growth and yield of coffee plants in agroforestry and monoculture systems in Minas Gerais, Brazil. Agroforestry Systems. 63: 75-82.

DeEll, J.R., Prange, R.K. (1993). Postharvest physiological disorders, diseases and mineral concentrations of organically and conventionally grown McIntosh and Cortland apples. Can. J. Plant Sci. 73: 223-230.

Dhyan Singh, P.K. Chhonkar, R.N. Pandey. (1999). Soil Plant Water Analysis, a Methods Manual. Indian Agricultural Research Institute Publication, New Delhi p 57-69.

El-Kader, A., Shaaban, S., El-Fattah, M. (2010). Effect of irrigation levels and organic compost on okra plants (Abelmoschus esculentus I.) grown in sandy calcareous soil. Agric. Biol. J. N. Am. 1(3): 225-231.

F.A.O. (2006). Plant Nutrition for Food Security-A Guide for Integrated Nutrient Management. [(ed). Roy. R.N., Finck. A., Blair, G.J and Tandon, H.L.S.] FAO, Fertilizer and Plant Nutrition Bulletin. 16: 3-16.

Gafar, A.F., Yassin, M., Ibrahim, D. and Yagoob, S.O. (2014). Effect of different (bio organic and inorganic) fertilizers on some yield components of rice (Oryza sativa L.). Universal Journal of Agricultural Research. 2(2): 67-70.

Gomez, K.A. and Gomez, A.A. (eds). (1984). Two Factor Experiments. In: Statistical Procedure for Agricultural Research. New York. Wiley.

Henrique, V. De Amorim. (1970). Nutritional Status of the Coffee Plant and Beverage Quality. Indian Coffee, XXXIV, NO. 12: 331-335.

Ibrahim, A., El-Samad, G. (2009). Effect of different irrigation regimes and partial substitution of $\mathrm{N}$-mineral by organic manures 
on water use, growth and productivity of Pomegranate trees. Eur. J. Sci. Res. 38(2): 199-218.

Inge de Groot. (2001). Effects of environmental measures on the sustainability indicators health and quality-Dilemmas and strategic choices. The report submitted to the "Suscof" project on sustainable coffee in Costa Rica. 56-69.

Jackson, M.L. (1973). Soil Chemical Analysis. Prentice Hall of India Pvt. Ltd., New Delhi, 498.

Jayarama. (2001). Optimal Nutrient Rates and their Best Management in Coffee Plantations. Indian Coffee. Vol 8-14.

Kesavamurthy, R.C. (1971). Chemical fertilizers and coffee cultivation. Indian Coffee, XXXV, No. 11: 471-472.

Kotchi, J. (ed.). (1990). Eco-Farming Practices for Tropical Smallholdings. GTZ Tropical Agroecology [5].

Krishnamurthy Rao, W. and Ramaiah, P.K. (1993). Soil and weather profiles of Indian coffee tracts, Indian Coffee, LVII, NO. 9: 3-5.

Kutywayo, D., Chingwara, V., Mahoya, C., Chemura, A and Masaka, J. (2010). The effect of different levels of irrigation water and nitrogen fertilizer on vegetative growth components and yield of coffee in Zimbabwe. MSU. J. Sci. Tech. 2(2): 45-54.

Linder, M.C. (1991). Food Quality and Its Determinants, from Field to Table: Growing Food, Its Storage and Preparation, In: Nutritional Biochemistry and Metabolism with Clinical Applications. [Linder, M.C., Ed.]. The Netherlands: Elsevier. 329-348.

Mahajan, A., Bhagat, R.M. and Gupta, R.D. (2008). Integrated nutrient management in sustainable rice wheat cropping system for food security in India. SAARC Journal of Agriculture. 6(2): 29-32.

Nagy, S. and Wardowski, W.F. (1988). Effects of Agricultural Practices, Handling, Processing and Storage on Fruits, In: Nutritional Evaluation of Food Processing. [Karmas, E. and Harris, R.S., (Ed)]. $3^{\text {rd }}$ Edition, New York: Van Nostrand Reinhold. 73-100.

Nyalemegbe, K.K., Oteng, J.W. and Asuming-Brempong, S. (2009). Integrated Organic-Inorganic Fertilizer Management for Rice Production on the Vertisols of the Accra Plains of Ghana. West African Journal of Applied Ecology. 16: 2332.

Nataraj, D.S. Ananda Alwar, R.P., Raghuramulu, Y. and Basavaraj, K. (1998). Quality coffee - An insight. Indian Coffee, LXII, NO. 2: 21-27

Raghavan, B. and Ramalakshmi, K. (1998). Coffee: Chemistry and technology of its processing. Indian Coffee, LXII, NO. 11: 3-11.

Randhawa, J.S., Sharma, R., Chhina, G.S. and Kaur, M. (2020). Effect of integrated nutrient management on productivity and quality of malt Barley (Hordeum distichon L.). Agricultural Science Digest. 40(3): 265-269.
Sangma, D.M., Longkumer, L.T., Singh, A.P. and Solo, V. (2021). Effect of Planting Density and Integrated Nutrient Management in Sesame (Sesamum indicum L.). Agricultural Science Digest. DOI: 10.18805/ag.D-5247.

Sodavadiya, H.B., Patel, V.J. and Sadhu, A.C. (2021). Effect of integrated nutrient management on the growth and yield of chickpea (Cicer arietinum L.) under chickpea - forage sorghum (Sorghum bicolor L.) cropping sequence. Legume Research. DOI: 10.18805/LR-4465.

Söndahl, M.R., Van der Vossen, H.A.M., Piccin, A.M. and Anzueto, F. (2004). The Plant. In: Espresso Coffee: The Chemistry of Quality, [Rino, R. (Ed.)] $2^{\text {nd }}$ edition. Academic Press Ltd, London.

Stiles, W.C., (1994). Nitrogen management in the orchard. In: Peterson, A.B., Stevens, R.G. (Eds.), Tree fruit nutrition: A comprehensive manual of deciduous tree fruit nutrient needs. Good Fruit Grower, Yakima, WA, pp 41-50.

Stockdale, E., Shepherd, M., Fortune, S. and Cuttle, S. (2002). Soil fertility in organic farming systems-fundamentally different? Soil use. Manag. 18: 301-308

Tesfaye Bayu. (2020). Review on contribution of integrated soil fertility management for climate change mitigation and agricultural sustainability, Cogent Environmental Science. 6(1): 1823631.

Tiemann, T., Aye, T.M., Dung, N.D., Tien, T.M., Fisher, M., de Paulo, E.N., Oberthür, T. (2018). Crop nutrition for Vietnamese Robusta coffee. Better Crop. Plant Food. 102: 20-23.

Tyagi, P.K., Upadhyay, A.K. and Raikwar, R.S. (2014). Integrated nutrient management of summer green gram. The Bioscan. 9(4): 1529-1533.

Van Der Vossen, H.A.M. (2005). A critical analysis of the agronomic and economic sustainability of organic coffee production. Expl Agric. 41: 449-473.

Van Der Vossen, H.A.M. (2004). Organic Coffee Production: Myth or Reality - A Review. $20^{\text {th }}$ International Conference on Coffee Science, Bangalore, $11^{\text {th }}-15^{\text {th }}$ October, 2004.

Van Elzakker, B. (2001). Organic Coffee. In: Coffee Futures: A Source Book of Some Critical Issues Confronting the Coffee Industry. [Baker, P.S. (ed.)] CABI-FEDERACAFE Commodities Press. CABI Bioscience Egham, UK. pp. 74-81.

Wang, J., Shen, H., Sun, J., Zhen, G., Liu, H., Li, Y., Zhao, B. and Zhang, F. (2002). Effect of long-term fertilization on crop yield, fertilizer and water use efficiency. Plant Nutr. Fert. Sci. 8: 82-6.

Worku, M. and Astatkie, T. (2010). Dry matter partitioning and physiological response of Coffea arabica varieties to soil moisture deficit stress at the seedling stage in Southwest Ethiopia. Africa J. Agric. Res. 5(15): 2066-2072.

Yitagesu, Y.H. and Shimels, S. (2020). Nutrition requirement, management and factor affecting on yields of arabica coffee (Coffea Arabica L.): Review. World Journal of Aquaculture Research and Development. 2: 04-10. Article 1008. 